DOI: 10.20472/EFC.2017.008.006

\author{
DARIUSZ PIOTROWSKI \\ Nicolaus Copernicus University in Toruń, Poland
}

\title{
CHALLENGES AND BARRIERS TO THE DEVELOPMENT OF SUKUK IN THE EUROPEAN CAPITAL MARKET
}

\begin{abstract}
:
Sukuk are instruments of the capital market whose construction is based on the sharia rules. Over the last two decades, the sukuk market has become global. However, the main centres of trade are still located in South-Eastern Asia, with Malaysia at the forefront, and countries in the Persian Gulf region. Sukuk are present in the European financial market, mainly through companies' issues and the functioning of centres of trade in London, Luxembourg and Dublin. Despite that, the Islamic certificates have not yet gained significant interest. The paper will indicate the types of challenges and barriers related to issuing and trading sukuk in the European market. The research applies an analysis of literature on the subject, reasoning based on statistical data regarding the European market and a case study of a 2014 sukuk offering transacted by the government of the United Kingdom. The paper indicates that the specific characteristics of sukuk lead to the conclusion that they should be treated as a separate category of capital market instruments. In consequence, trading in these instruments on the European financial market requires an adjustment of the applicable legal norms. What is more, the fact that sukuk's structure is more complicated than that of traditional financial instruments increases risks and costs of the issuers. The distinctness and variety of sukuk forms hinder financial risk assessment, and thus have a negative impact on the scale of investors' interest in sukuk.
\end{abstract}

\section{Keywords:}

Sukuk, Islamic finance, European financial market, development barriers

JEL Classification: G18, 016, Z12 


\section{Introduction}

Islamic finance has evolved in recent decades from a set of theoretical considerations constituting an element of Islamic economics to a system incorporating institutions and financial instruments functioning on the basis of the sharia rules. The specific and distinctive nature of the Islamic financial system is generally associated with the ban on earning unreasonable returns on contracts or financing activities deemed prohibited. It is far less accentuated that the cornerstones of Islamic finance also include the promotion of active participation in business ventures where the opportunity to achieve profit is connected with the risk of incurring losses.

In the 1990s, the Islamic financial system saw the advent of its own capital market, as separate from dominant Islamic banking and insurances. At first, the offered products included funds investing money in raw materials, real property market and shares in companies approved by sharia councils within a screening process. The introduction of sukuk, a new category of financial instruments, should be associated with the need to develop an Islamic counterpart of conventional bonds. Institutions of the Islamic financial market, experiencing dynamic growth, were expecting instruments which could be applied both in liquidity management and to finance investments (Greuning and lqbal, 2008).

In the recent 10 or 15 years, the sukuk segment has recorded the most dynamic growth in the whole area of Islamic finance. The factors behind the success of this innovation include the diversity of its construction, its practical application and the proliferation of Islamic certificates in the international financial markets. The primary sukuk issuers are the governments and public institutions of countries in Southeast Asia and in the Persian Gulf region. Sukuk offerings are primarily a form of raising capital, but are also often an element of strategies aiming to develop centres for Islamic finance. In recent years, European entities have also demonstrated interest in sukuk, what resulted in issues carried out by governments of the United Kingdom and Luxembourg.

The main purpose of the paper is to indicate the most important challenges and barriers related to sukuk issuances and sukuk trade in the European market. It identifies financial, legal and social factors which have a bearing on the scale of interest in sukuk. The considerations are preceded by a study of the nature of sukuk together with an indication of features differentiating them from conventional instruments. The research includes an analysis of existing sources regarding the subject matter, inference based on statistical data referring to the global and European sukuk market, and a case study of the offering of Islamic certificates made in 2014 by the government of the United Kingdom.

\section{The nature of sukuk - theoretical and empirical approach}

Contrary to widespread opinions, the world of Islam is not unified, it is internally varied. One of the reasons behind the divisions are the accepted sources of religious law. The multitude of views of sharia schools on the issue of business contracts has not aided 
the development of instruments of the Islamic financial market. However, certain steps were taken to harmonise regulations within the Islamic financial market, e.g. by establishing institutions, such as the Accounting and Auditing Organization for Islamic Financial Institutions (AAOIFI) and the Islamic Financial Services Board (IFSB). Among other tasks, these bodies have undertaken to work out sukuk standards. The most frequently cited standard is the one proposed by the Accounting and Auditing Organization for Islamic Financial Institutions (2008), pursuant to which sukuk are certificates of equal value representing undivided shares in ownership of tangible assets, usufruct and services or (in the ownership of) the assets of a particular projects or special investment activity, however, this is true after receipt of the value of the sukuk, the closing of subscription and the employment of funds received for the purpose for which the sukuk are issued. On the other hand, the Islamic Financial Services Board (2009) defines sukuk as certificates with each sakk representing a proportional undivided ownership right in tangible assets, or a pool of predominantly tangible assets, or a business venture. These assets may be in a specific project or investment activity in accordance with Shari ah rules and principles.

As was mentioned above, sukuk is a diverse category of financial instruments, because in their structure they use many traditional techniques of Islamic finance, which in turn refer to different assets, such as tangible assets, usufructs, debts, money, services, financial rights or a mixture of some or all of these kinds (Shari'a and Fatwa Supervisory Board, 2013). AAOIFI has indicated 14 sukuk types which may be grouped into two categories: instruments based on investment contracts and instruments based on financial contracts. The division is important in terms of whether sukuk may be traded in the secondary market.

One of the principal prohibitions formulated in the Koran regards riba, i.e. an unjust, excessive surplus, often equated with interest. The ban or significant limitations on the collection of surplus have an effect on the rules of trade in capital market instruments. The market value of sukuk is allowed to vary from their face value in the case when the market value of the underlying assets fluctuates. In light of the above, sukuk confirming a share in joint ventures or benefits deriving from assets may be traded in the secondary market. This is possible when sukuk are based on the mudaraba, musharaka and ijara techniques. On the other hand, if sukuk are structured around assets which are purchased or manufactured for sale, it puts significant limitations on trade in such instruments. This happens because the sukuk structure becomes too similar to debt or cash trading. Due to the threat of riba, sukuk based on the salam, istisna' and murabaha techniques may be traded only at nominal value. As a result, sukuk of a financial nature are commonly held to maturity (Ayub, 2007).

The analysis of available literature indicates that sukuk have certain features of bonds, revenue bonds, shares and investment certificates. Depending on the type of construction underlying sukuk, there is a varying degree of similarity to the abovementioned conventional instruments. In literature, sukuk are often named Islamic bonds, what may stem from the similarity of functions performed and the like nature of cash flows related to the servicing of those instruments. As in the case of 
bonds, sukuk are traditionally issued for a definite period, and the investor exchanges the funds provided to the issuer for the right to receive periodic payments and to demand redemption of instruments on maturity. However, the basic difference between those instruments consists in the fact that sukuk may not involve riba. They also vary in terms of the transaction structure, the nature of investment and the manner of collecting benefits (Islamic Financial Services Board, 2013). In the case of sukuk, payments are connected with the instrument's underlying asset, while in the case of bonds with the issuer's obligation. The association of periodic payments to investors with the venture funded through a sukuk issue points to a similarity to revenue bonds. However, with sukuk the cash flows are not related to debt, but rather to a share-based exposure. Such participation in the venture is approved by Islam because gaining profit and increasing wealth are coupled with a risk of incurring losses (Iqbal, and Mirakhor, 2007). The definitions of sukuk presented in this paper highlight this very aspect, and thus bring those instruments closer to shares and investment certificates. However, the chief factor differentiating them from shares is their time of functioning which is usually determined and limited. Moreover, sukuk do not represent shares in a company which commonly performs different types of activities, but rather in an individual project or investment venture. In the case of shares, their owners decide on whether to pay dividend and what it will amount to. What is more, shareholders do not have to directly participate in the company's losses (participation is indirect through decreased share price). On the other hand, the terms and conditions of a sukuk issue determine the share in profit or loss of the funded venture. Another solution, albeit its adherence to the sharia law is sometimes questioned, provides for a predetermined rate of return on sukuk. It seems that sukuk show most similarities to investment certificates, and therefore it would be justified to name them Islamic certificates. Both instruments have a determined maturity. They also represent a share in ventures, but while it is always a direct share with sukuk, it may also be indirect the case of certificates, e.g. through purchase of shares. Profit on sukuk is primarily obtained in the form of periodic payments, whereas a certificate holder gains on the increase in the certificate's market value.

The results of many empirical studies also confirm that sukuk should be treated as a separate category of financial instruments. The papers presented below compared data obtained from liquid sukuk markets with values describing bond or stock markets. The results of research by M. Ariff and M. Safari (2015) suggest that sukuk and conventional bonds are distinct instruments because they are priced in a significantly different way. H.H. Mohamed, M. Masih and O.I. Bacha (2015) showed that the behaviour of Malaysian issuers with respect to choosing how to raise capital proved that they saw differences between sukuk and bonds, but also between exchangebased sukuk and partnership-based sukuk. Another study covering the Malaysian debt market indicated that in terms of risk and yield, sukuk are somewhere in between the safe government bonds and the more profitable corporate bonds (Ramasamy et al., 2011). Other papers noticed a varied reaction in the capitalisation of Malaysian listed companies to information on the issuance of conventional bonds and sukuk. However, in one instance the investors' reaction to sukuk issues was negative (Godlewski et al., 
2010; Alam et al., 2013), while other results indicated that investors reacted positively to the announcement of Islamic debt issues (Ibrahim and Minai, 2009). In turn, a study analysing the effectiveness of portfolios composed of Eurobonds and sukuk of the same issuers based in Malaysia, Pakistan, Qatar and Bahrain detected material differences in the behaviour of the two instruments (Cakir and Raei, 2007). A. Sclip, A. Dreassi, S. Miani and A. Paltrinieri (2016) also argued that sukuk may be used as an alternative class of instruments which may serve to diversify an investment portfolio. The analysis of the movements of Dow Jones Citigroup Sukuk Index, Dow Jones Citigroup Global bond index, Dow Jones Islamic Market Index and finally the Dow Jones Global Index showed low returns and volatility transmissions between the sukuk market and the bond market and determined that sukuk has a transmission mechanism to (from) global equities that is different from conventional bonds (Maghyereha and Awartanib, 2016).

\section{The global sukuk market}

The assets of the Islamic financial market constitute around $1 \%$ of global financial assets (Statistical, Economic and Social Research and Training Centre for Islamic Countries, 2012). As at the end of 2015, their value was estimated at USD 2,004 bn. When judging this value, it should be highlighted that the sharia-based financial system is relatively young because it started functioning in the 1970s. The banking sector has a dominant share in the Islamic financial sector in terms of assets managed (USD 1,451 bn, 73\%), and it is followed by the Islamic capital market together with its most important part, i.e. the sukuk segment (USD 342 bn, 17\%) (ICD-Thomson Reuters, 2016).

Chart 1 presents the total number and value of sukuk issuances carried out on the global scale during nearly the entire existence of the market. An analysis of the presented data pinpoints a positive trend in terms of the value of offerings made. Apart from the strong correction in 2008 resulting from the global financial crisis, this trend continued until 2012. Although during the following year the number of issuances was still rising, in terms of value the sukuk market has been experiencing a downward trend since 2013. The general behaviour of the sukuk market is determined by the state of the global economy, as well as changes in the economic and political situation in the main issue centres, which in turn are strongly influenced by prices of raw materials. The most important events and processes which have had an effect on that market in recent years include: the global financial crisis and the quantitative easing policy aimed to help economies recover, the effect of the decision of the Central Bank of Malaysia to stop issuing short-term sukuk in 2015, or the fact that issuers from Islamic countries prefer bonds to sukuk due to lower costs and a less complicated structure (S\&P Global Ratings, 2016). 


\section{Chart 1. Global sukuk issuance (1996-YTD Q3 2016)}

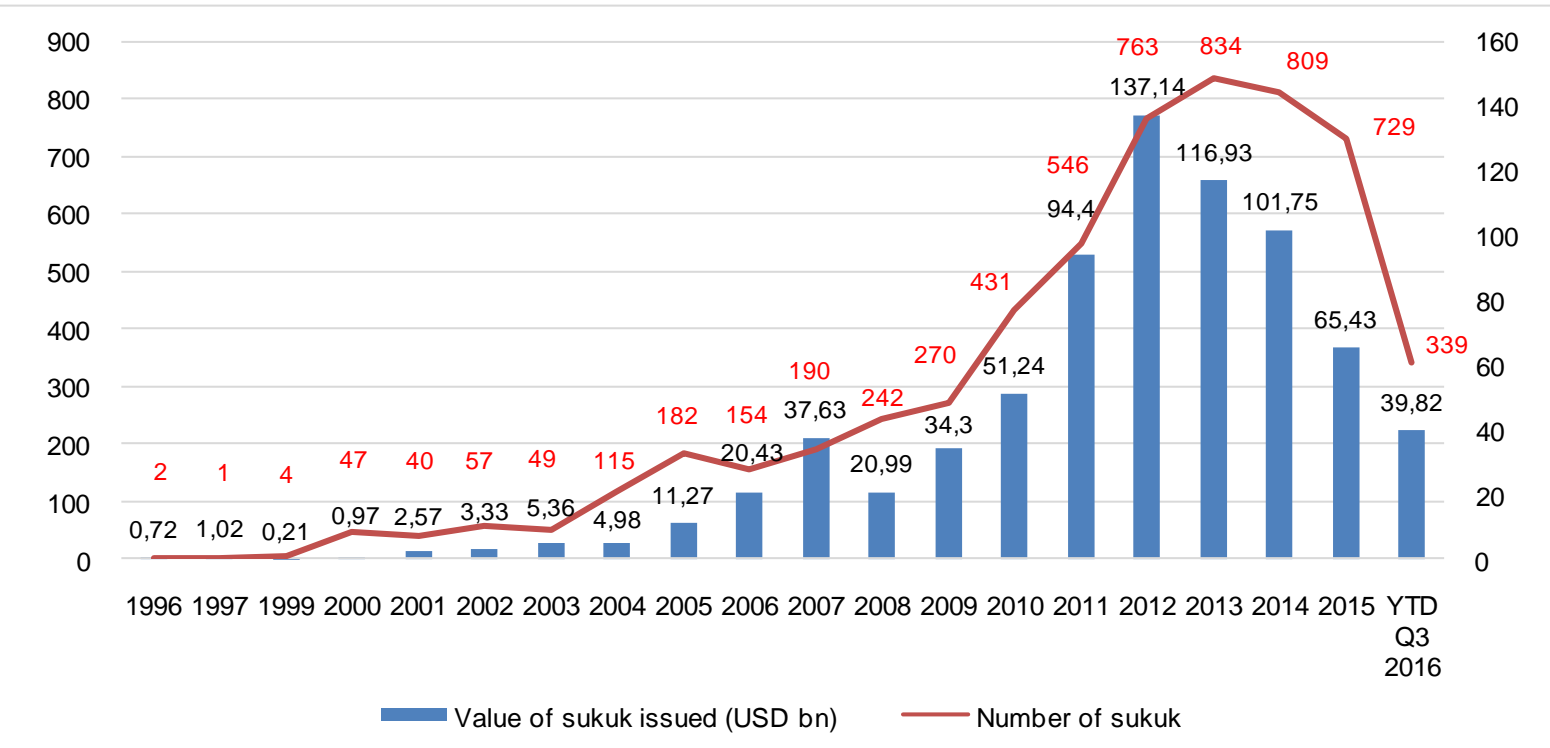

Source: Thomson Reuters. (2016). Sukuk Perceptions and Forecast Study 2017: Poised for Growth, p.27. Available at: https://www.slideshare.net/EzzedineGHLAMALLAH/thomson-reuters-sukukpreceptions-and-forecast-study-2017 [Accessed 19 March 2017].

Available market data help analyse the structure of the sukuk market in terms of issuer type. This information suggests that public entities, including governments, central banks and state-owned institutions and enterprises are slightly more active than the private sector. The activities of public entities, both in the regulatory area and in the field of offerings made, have had a considerable impact on the inception and development of the sukuk market (Alim, 2013) ${ }^{1}$. The situation in world economy, which has been improving for several years since the onset of the crisis in 2008, has been favourable to offerings made by private entities. The domination of this type of issuers was particularly visible in the international sukuk segment. In response to the financial crisis, which also affected the sukuk market, there has been an increase in the share of sovereign issuances both in the domestic and international sukuk segments (Alvi et al., 2014). Public issuances in the sukuk market were a form of supporting the market in the difficult period, and were intended to introduce some stability. This ultimately resulted in increased trust between market participants. The last three years in the analysed period again demonstrated the continued, relatively high share of issuances carried out by private entities and offerings targeted at foreign markets (Thomson Reuters 2016).

\footnotetext{
${ }^{1}$ It is assumed that the first issue of modern sukuk took place in 1983, when the Malaysian government launched a government bond known as government investment certificate based on the concept of Qard al-Hasan (benevolent loans). Literature often suggests that the beginning of the sukuk market should be associated with the issue carried out in 1990 in Malaysia by Shell MDS.
} 


\section{Chart 2. Top 10 countries in sukuk volume outstanding (FYE 2015)}

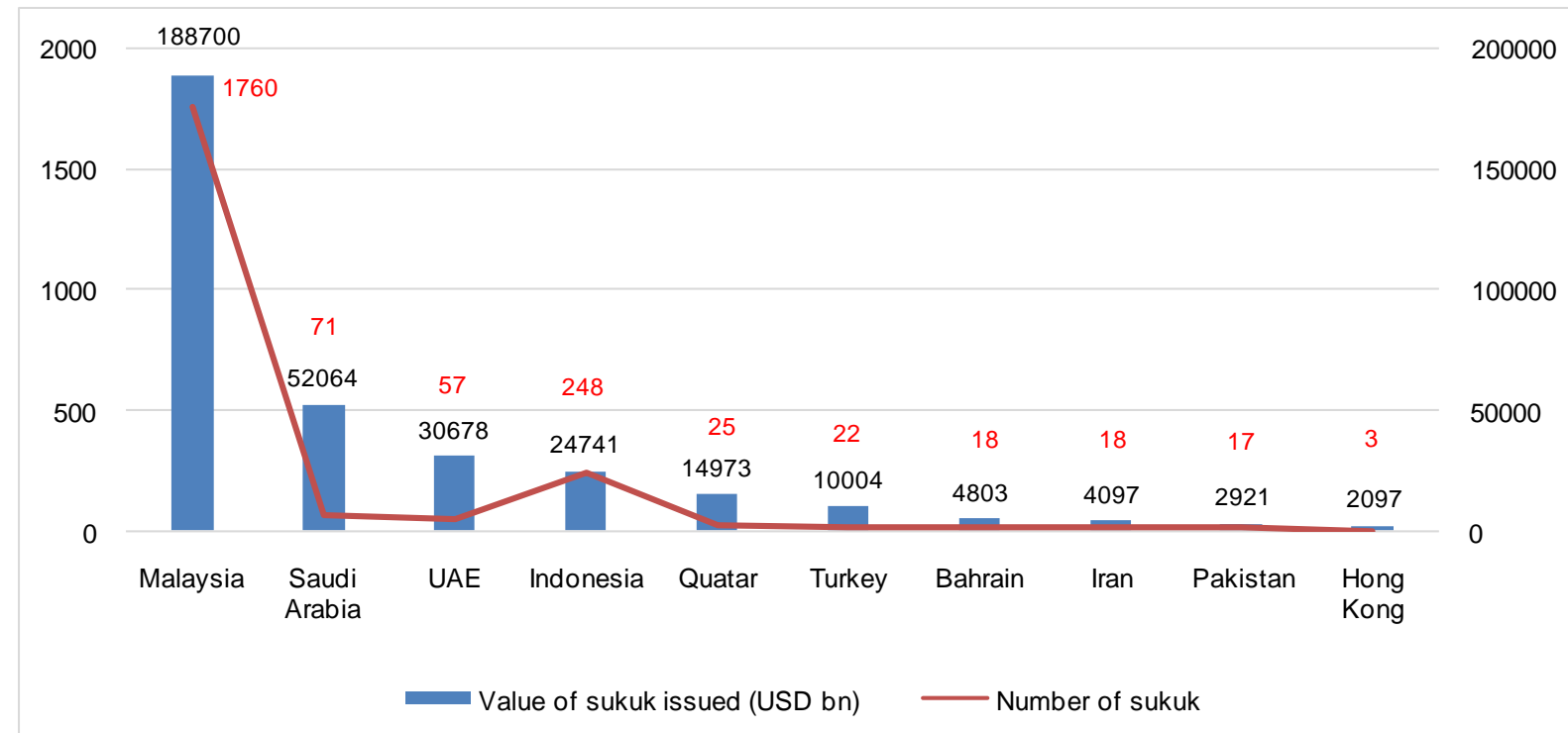

Source: Thomson Reuters. (2016). Sukuk Perceptions and Forecast Study 2017: Poised for Growth, p.25. Available at: https://www.slideshare.net/EzzedineGHLAMALLAH/thomson-reuters-sukukpreceptions-and-forecast-study-2017 [Accessed 19 March 2017].

Sukuk offerings are made primarily in Muslim countries. The data presented in chart 2 indicate that the largest primary markets for those instruments include Malaysia, Saudi Arabia, the United Arab Emirates, Indonesia and Qatar. Recent years have seen the débuts of sovereign sukuk offerings in Turkey, Iran, Senegal, Oman, Ivory Coast, Togo, and Jordan, among other countries. The governments of Kazakhstan, Kenyon, Morocco, Nigeria, Niger and Tunisia intend to follow suit in the near future. Entities from countries outside the Organisation of Islamic Corporation, such as the United Kingdom, Luxembourg, the Republic of South Africa and Hong Kong, also carried out issuances (Alim et al., 2014). Selected features of the abovementioned issuances are presented in table 1.

Table 1. Début sovereign sukuk issuances carried out between 2014 and 2016

\begin{tabular}{|l|c|c|c|c|c|}
\hline Country & Issue date & Structure & $\begin{array}{c}\text { Issue size } \\
\text { (USD mln) }\end{array}$ & Currency & $\begin{array}{c}\text { Tenor } \\
\text { (years) }\end{array}$ \\
\hline United Kingdom & June 2014 & Ijara & 334 & GBP & 5 \\
\hline Senegal & July 2014 & Ijara & 208 & XOF & 4 \\
\hline Hong Kong & September 2014 & Ijara & 1000 & USD & 5 \\
\hline South Africa & September 2014 & Ijara & 500 & USD & 5,75 \\
\hline Luxembourg & September 2014 & Ijara & 252,5 & EUR & 5 \\
\hline Oman & October 2015 & Ijara & 650 & OMR & 5 \\
\hline Ivory Coast & December 2015 & Ijara & 244 & XOF & 5 \\
\hline Iran & March 2016 & Ijara & 145 & IRR & 4 \\
\hline Togo & July 2016 & Ijara & 251 & XOF & 10 \\
\hline Jordan & October 2016 & Ijara & 47,9 & JOD & 5 \\
\hline
\end{tabular}

Source: www.sukuk.com [Accessed 10 March 2017]. 
Data in table 1 suggest that the only structures used were based on the Islamic ijara contract, the issuances raised several hundred million dollars each, and most instruments had a maturity of five years.

\section{Sukuk market in Europe}

European financial institutions have already gained some experience in the field of sukuk. In 2002, i.e. in the initial phase of the global sukuk market, these instruments were first listed at the Luxembourg Stock Exchange (Mauro et al., 2013). In late 2016, around 80 different sukuk issuances were listed on European stock exchanges, mainly in London, Frankfurt, Luxembourg and Dublin. This makes those markets important centres of trade in Islamic certificates on the global scale. The success in creating a secondary market for sukuk should be associated with several factors. Firstly, the abovementioned stock exchanges are an element of conventional financial hubs whose functions include the mobilisation, allocation, transfer and valuation of capital. Secondly, the fact that these centres have been providing services in the field of Islamic finance since the 1990s has contributed to the development of a specialised market environment composed of financial and legal advisory companies dealing with instruments observing sharia requirements. Thirdly, the development of most of the abovementioned markets was supported by governmental activity aimed at creating hubs for Islamic finance.

The first sukuk offering in Europe was carried out relatively early, in 2004. As a result of issuing Islamic certificates, the German state of Saxony-Anhalt raised EUR 100 million on the market. Despite the promising beginnings of the primary sukuk market, the total number of offerings carried out by European entities by the end of 2016 did not exceed twenty and the total value of funds raised was several billion dollars. It should be noted that most of this sum was obtained by issuers from Turkey, and the widely-publicised offerings made by the governments of the United Kingdom and Luxembourg were more of an element of the abovementioned strategies to build centres for Islamic finance, rather than a method to fund state borrowing needs. These assertions are supported by the meagre values of the offerings in terms of public finance and the fact that they were not repeated.

Only two or three years ago, representatives of many institutions operating in the world of Islamic finance presented optimistic scenarios for the development of the European sukuk market, in particular its corporate segment. The forecasts expected a rise in the number of corporate offerings encouraged by sovereign sukuk issuances (Bank Negara Malaysia, 2015). Sukuk issuances were to help European companies raise money to finance infrastructure and investment projects, and create an opportunity for investors from the Middle East and Asia to allocate capital in shariacompliant assets on mature markets (Deloitte). These scenarios also assumed a rising interest of European investors in alternative investment opportunities (Latham\&Watkins LLP, 2015a). What is more, they expressed a view, objected to by the author, that "the credit crunch in the US and Europe, coupled with the ongoing 
Eurozone crisis, has resulted in more companies turning to the increasingly liquid sukuk market" (Latham\&Watkins LLP, 2015b).

\section{Barriers and challenges for the participants of the European sukuk market}

The data presented above show the negligible importance of sukuk as an instrument for raising funds for European entities from the public and private sector. Therefore, it is worth identifying the factors limiting the development of the sukuk market in Europe. The available sources indicate that the following macroeconomic factors have an impact on the sukuk market: GDP per capita, Muslim population, economic size, trade openness and regulatory quality (Said and Grassa, 2013). The standardisation of sukuk construction and regulations regarding bankruptcies of sukuk issuers are also notable (Latham\&Watkins LLP, 2015a). The author of the paper also draws attention to governments' attitude towards the Islamic finance sector in different countries and the need to consider factors significant for individual issuers, such as cost and speed of raising capital and the degree of complexity of the funding structure. The analysis of individual factors should take into account the fact that they may have a different impact on public issuers and enterprises. Furthermore, a separate analysis should be carried out in terms of barriers to market development for issuers and for investors.

In general, European governments have no problems in raising funds through the issue of conventional bonds, and therefore significant sukuk issuances on their part should not be expected. It is also important for the analysis of the prospects for the development of the sukuk market to take into account the fact that when carrying out the said offerings, governments could accommodate higher costs of raising capital, a longer period of waiting for the funds, or the more complex process of structuring the transaction than in the case of bonds because their motives were often not purely financial. In fact, the activity of states in the sukuk market may serve to set a benchmark for corporate offerings, promote those instruments as a form of Socially Responsible Investment or, from a broader perspective, be a part of strategies for building centres of Islamic finance (Piotrowski, 2017).

In light of the expected small-scale activity of public issuers, the only way to boost the development of the sukuk market in Europe is to increase the number and value of offerings made by companies. However, research performed by Deloitte (2015) proves that European enterprises are not aware of the existence of sukuk. What is more, companies make their decisions based primarily on economic calculations. They consider not only the direct issuance costs, which are usually higher than in the case of conventional bonds, but also barriers to demand resulting from a small investor base, and the distinctness and considerable complexity of the construction of those Islamic instruments. One of the factors which should also be borne in mind is the potential negative effect of the announcement of a sukuk issuance on company value (Alam, Hassan, and Haque, 2013). 
The current global economic situation does not favour sukuk offerings because market practice indicates that sukuk issuances are more frequent in times of market growth, when investors are more prone to experimenting with new forms of raising capital and can afford to use instruments with higher servicing costs, albeit better reflecting the values they share. The situation observed in recent years in the debt market of the Gulf states confirms the view regarding the low profitability of sukuk: the increased borrowing needs of Arab states caused by the drop in prices of raw materials and emerging fiscal deficits are funded mainly through issues of the cheaper and simpler conventional bonds (Thomson Reuters, 2016).

Data included in chart 2 point to the fact that around ten Islamic countries managed to create a relatively developed sukuk market. This may lead to a conclusion that the market of Islamic certificates has a chance to function in only a few European countries. Due to their experience in providing Islamic finance services and high GDP per capita, these may include the United Kingdom, Luxembourg, Ireland, France, Turkey and Germany. However, small economies and no substantial Muslim communities raise doubts as to the development of a primary sukuk market in Luxembourg and Ireland.

The report on corporate sukuk developed by Deloitte (2015) argues that the United Kingdom has the greatest potential among European countries for the development of that market. The analyses, taking into account the social, legal and tax areas and the policy environment, suggested that Turkey and France were next highest in the ranking. Germany was ranked lowest on that list because it demonstrated significant shortcomings in terms of legal regulations dedicated to Islamic finance, in particular those ensuring tax neutrality.

The author believes that developing relevant legal and tax regulations covering this market segment is a basic prerequisite for the development of the sukuk market. European countries may take the example of Luxembourg, Ireland, and in particular the United Kingdom, which has adopted regulations under which sukuk are a form of alternative finance investment bonds. This has allowed the market to treat sukuk as bonds from the legal perspective, and the issuers to recognise the periodic payments to investors as tax deductible costs, similar to interest on bonds. As early as in 2003, the United Kingdom removed the double charge through the Stamp Duty Land Tax. It was one of many operations intended to ensure sukuk's tax neutrality against bonds (United Kingdom Trade \& Investment, 2014).

Uncertainty regarding the compliance of sukuk construction and the terms and conditions of sukuk issuances with the sharia law is another factor imposing certain limitations of the development of the market. This risk should be associated with the vagueness and variability of legal interpretations of sharia schools, or conflicts between court judgements based on civil or common law and the sharia-based principles (Al-Bashir and Al-Amine, 2012). The best-known example dates back to 2007 and concerns Taqi Usmani questioning the compliance with sharia of a staggering $85 \%$ of sukuk issued by Persian Gulf entities (International Islamic Financial Market, 2009). 
The author views sukuk's complex structure as the strongest barrier to the development of the sukuk market, both on the European and global scale. As the construction sukuk is based on assets, it involves transferring assets between entities included in transaction structuring. Therefore, it becomes necessary to value the transferred assets, pay taxes and fees related to this process and bear administrative costs entities responsible for managing sukuk owners' assets (Jobst et al., 2008).

An analysis of HM Treasury's documents $(2007 ; 2008 ; 2014)$ related to the sukuk issuance made by the British government revealed the magnitude of work that had to be done. Although in the case of further issuances, government or corporate, the scope of necessary regulatory operations would be much smaller, the main source of additional costs as compared to conventional bond issuances remains the same: it is the complex legal, organisational and ownership structure underlying the sukuk construction.

\section{Diagram 1. UK Government sukuk structure and cash flows}

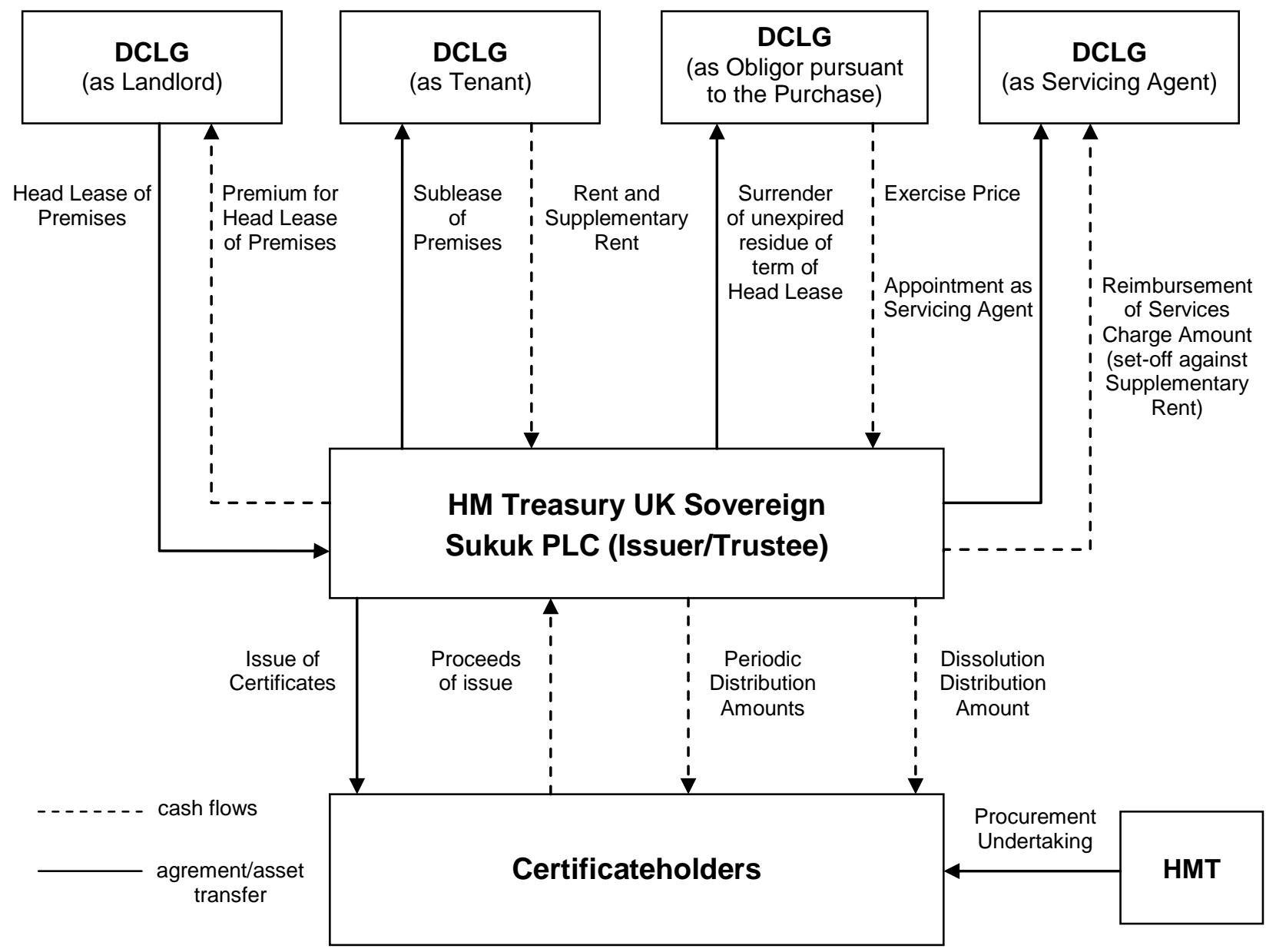

Source: HM Treasury. (2014). HM Treasury UK Sovereign Sukuk PLC. Offering circular, London: HM Treasury, p.10. 
The sukuk construction presented in diagram 1 shows the entities involved in the process, their functions and legal and financial operations. When analysed, the diagram confirms the view that sukuk construction is usually more complex than in the case of bonds which in fact can only have an issuer, investors and cash flows related to the servicing of debt. In the case of the presented offering, the transaction included the acquisition of a 99-year lease of plots of land and buildings used for governmental purposes. On the issue date, the Trustee received the price from Certificateholders and paid it under the Head Lease to the Secretary of State for Communities and Local Government (DCLG). Subsequently, the properties were sub-leased back to DCLG in return for DCLG making periodic rental payments. What also confirms the complexity of the structure is the fact that the offering was prepared with the participation of many institutions, including HSBC, Barwa Bank, CIMB, National Bank of Abu Dhabi and Standard Chartered Bank, and the matters of sharia compliance of the transaction documents were supervised by Bait Al-Mashura Finance Consultations Company, Shariah Committee of CIMB Islamic Bank Berhad, the Executive Shariah Committee of HSBC Saudi Arabia Limited and Standard Chartered Bank Shariah Supervisory Committee.

The primary purchasers of sukuk on the global scale are institutional investors, although the significance of individual investors should not be omitted in analyses regarding the development of the market. In the case of the European market, it may be assumed that both investor categories do not have sufficient knowledge and experience regarding the functioning of sukuk. The distinctiveness and variety of sukuk forms may make investors unaware of the different risks. This, in turn, may translate into capital losses and the loss of interest in the new category of instruments. Liquidity risk is pivotal in the case of sukuk. Difficulties in disposing of the instruments may discourage certain investors. The European Central Bank has also indicated legal risk as a significant restriction on the development of the sukuk market. This risk is related to the choice of legal basis for the issuance, the indication of the entity responsible to investors and the assets used to satisfy investor claims (Mauro et al., 2013). Theoretically, the construction of the analysed instruments is based on assets, and this should ensure a source of income and the protection of investors' assets in the case of bankruptcy of sukuk issuers on the one hand, and sharia compliance on the other. However, in practice issuers prefer using asset-based structures to assetbacked ones with an actual transfer of rights to assets to sukuk purchasers. The results of the survey by Thomson Reuters carried out in mid-2014 among 106 entities representing the demand side of the sukuk market indicate that the question of rights to assets is vital in the assessment of investment risk (Alim et al., 2014).

\section{Summary}

Sukuk are alternative financial instruments which have received attention from many participants of the financial market in recent years. However, the dynamic development of the market observed until the year 2012 did not contribute to the recognition of the sukuk segment as notable in terms of value. Sukuk issuances are a 
significant source for raising capital for governments and companies in only a few countries.

Although European stock markets are important secondary markets for sukuk, this does not convert into the development of the primary market for those instruments. The sukuk issuances discussed in the paper carried out by the governments of Luxembourg, the United Kingdom and Turkey were a cornerstone for market development. They were the outcome of many years of preparations covering the issues of legal and tax regulations aimed at improving the competitiveness of Islamic financial instruments. Unfortunately, individual government offerings did not result in a wider corporate use of those instruments. Corporate sukuk offerings have recently been practically non-existent, even despite the relatively favourable economic situation in Western European countries and interest in purchasing European sukuk voiced by investors from Islamic countries.

The author believes that there are two factors limiting the development of the sukuk market in Europe. The first barrier consists in the fact that the interested parties are barely aware that such category of instruments even exists. Improving the recognisability of and interest in sukuk requires educational activities focused on potential investors. In light of the specific nature of Islamic financial instruments, the efforts of sector representatives should also be aimed at increasing the number and competence of advisors servicing transactions in the legal and financial scope. Financial and promotional support granted by state authorities or trading markets to several corporate sukuk issues could prove extremely useful to market development.

The second and far more serious barrier regards the high complexity of the sukuk structure. Sukuk's nature means that they have a more complicated and varied construction, which makes it less clear than that of their conventional counterparts. This is also reflected in higher issuance costs. Legal and tax regulations adopted by certain European countries have certainly had a positive effect on the costattractiveness of sukuk. However, in order to match the competitiveness of sukuk with that of conventional instruments it is necessary to take up further challenges. It seems that stricter standardisation of the construction of Islamic instruments is the right direction.

The solutions proposed in the paper are not easy to implement and their effects may come in the longer term. However, it is worth taking steps to increase the recognisability and competitiveness of sukuk because a wide range of financial instruments and new opportunities for companies to raise capital are important benefits for the participants of the European capital market.

\section{References}

Accounting and Auditing Organization for Islamic Financial Institutions. (2008). Shari'a Standard No. 17 on Investment Sukuk. Manama: AAOIFI.

Alam, N., Hassan, M.K. and Haque, M.A. (2013). Are Islamic bonds different from conventional bonds? International evidence from capital market tests. Borsa Istanbul Review, 13(3), pp. 22-29. 
Al-Bashir, M., Al-Amine, M. (2012). Global Sukuk and Islamic Securitization Market. Financial Engineering and Product Innovation. Leiden-Boston: Brill.

Alim, E.A. ed. (2013). Sukuk Perceptions and Forecast Study 2014, Thomson Reuters Zawya.

Alim, E.A., Hasan S., Goud B., Al Ansari, R. and Eid, Z. (2014). Sukuk Perceptions and Forecast 2015. Beyond traditional markets, Thomson Reuters.

Alvi, I.A., Rufai, A., Dadabhoy, I., Khan, Z.G., Naseer, U.M., Nasser, B., Zarrar, S. and Fouad, T. (2014). Sukuk Report. A comprehensive study of the Global Sukuk Market, International Islamic Financial Market.

Al-Sayed, O. (2013). Sukuk Risk: Analysis and Management. European Journal of Applied Social Sciences Research, 1(3), pp. 67-76.

Ariff, M. and Safari, M. (2015). Valuation of Islamic debt instruments, the sukuk: Lessons for market development. In: H.A. El-Karanshawy, A. Omar, T. Khan, S.S. Ali, H. Izhar et al. ed., Islamic banking and finance - Essays on corporate finance, efficiency and product development. Doha: Bloomsbury Qatar Foundation.

Ayub, M. (2007). Understanding Islamic Finance. West Sussex: John Wiley \& Sons Ltd.

Bank Negara Malaysia. (2015). Europe: a rising opportunity for Islamic finance [online]. Available at: www.mifc.com [Accessed 12 March 2017].

Cakir, S. and Raei, F. (2007). Sukuk vs. Eurobonds: Is there a difference in value-at-risk? IMF Working Paper, 237.

Deloitte. (2015). Corporate Sukuk in Europe. Alternative financing for investment project [online]. Available at: https://www2.deloitte.com/ [Accessed 12 March 2017].

Godlewski, Ch.J., Turk-Ariss, R. and Weill, L. (2010). Are Islamic Investment Certificates Special? Evidence on the Post-Announcement Performance of Sukuk Issues, LaRGE Working Paper, 5.

Greuning, H. van, and lqbal, Z. (2008). Risk Analysis for Islamic Banks. Washington: The World Bank.

HM Treasury. (2007). Government sterling sukuk issuance: a consultation. London: HM Treasury, United Kingdom Debt Management Office.

HM Treasury. (2008). Government sterling sukuk issuance: a response to the consultation. London: HM Treasury, United Kingdom Debt Management Office.

HM Treasury. (2014). HM Treasury UK Sovereign Sukuk PLC. Offering circular. London: HM Treasury.

Ibrahim, Y., and Minai, M.S. (2009). Islamic bonds and the wealth effects: evidence from Malaysia. Investment Management and Financial Innovations, 6(1), pp. 184-191.

ICD-Thomson Reuters. (2016). Islamic Finance Development Report 2016: Resilient Growth, p.8. Available at: https://www.slideshare.net/EzzedineGHLAMALLAH/icd-thomson-reuters-islamicfinance-development-report-2016 [Accessed 18 March 2017].

Iqbal, Z. and Mirakhor, A. (2007). An Introduction to Islamic Finance. Singapore: John Wiley \& Sons (Asia) Pte Ltd.

International Islamic Financial Market. (2009). Sukuk Report. A comprehensive study of the Global Sukuk Market, Kuala Lumpur: IIFM.

Islamic Financial Services Board. (2009). IFSB Shari'a Standard No. 7, Capital Adequacy Requirements for Sukuk, Securitisations and Real Estate Investment. Kuala Lumpur: IFSB.

Islamic Financial Services Board. (2013). Disclosure Requirements for Islamic Capital Market Products. Kuala Lumpur: IFSB. 
Jobst, A., Kunzel, P., Mills, P. and Sy, A. (2008). Islamic Bond Issuance - What Sovereign Debt Managers Need to Know? IMF Policy Discussion Paper, PDP08/3.

Latham\&Watkins LLP. (2015a). The Sukuk Handbook: A Guide To Structuring Sukuk [online]. Available at: https://www.lw.com/thoughtLeadership/guide-to-structurings-sukuk-2015 [Accessed 12 March 2017].

Latham\&Watkins LLP. (2015b). Discussing the trends. The future of sukuk [online]. Available at: https://www.lw.com/ [Accessed 12 March 2017].

Maghyereha, A.I. and Awartanib, B. (2016). Dynamic transmissions between Sukuk and bond markets. Research in International Business and Finance, 38, pp. 246-261.

Mauro, F. di, Caristi, P., Couderc, S., Maria, A., di, Ho, L., Grewal, B.K., Masciantonio, S., Ongena, S. and Zaher, S. (2013). Islamic Finance in Europe. European Central Bank. Occasional Paper Series, 146.

Mohamed, H.H., Masih, M. and Bacha, O.I. (2015). Why do issuers issue Sukuk or conventional bond? Evidence from Malaysian listed firms using partial adjustment models. Pacific-Basin Finance Journal, 34, pp. 233-252.

Piotrowski, D. (2017). Government strategies based on sukuk issues. Eurasian Studies in Business and Economics, 4, pp. 67-78.

Ramasamy, R., Munisamy, S. and Helmi, M.H.M. (2011). Relative Risk Of Islamic Sukuk Over Government And Conventional Bonds, Global Journal of Management and Business Research, 11(6), pp. 4-12.

Sclip, A., Dreassi, A., Miani, S. and Paltrinieri, A. (2016). Dynamic correlations and volatility linkages between stocks and sukuk: Evidence from international markets. Review of Financial Economics, 31, pp. 34-44.

Shari'a and Fatwa Supervisory Board. (2013). DFM Standard For Issuing, Acquiring and Trading Sukuk. Exposure Draft. Dubai: SFSB.

Statistical, Economic and Social Research and Training Centre for Islamic Countries. (2012). Islamic Finance in OIC Member Countries. Ankara: SESRIC.

Said, A., and Grassa, R. (2013). The determinants of sukuk market development: does macroeconomic factors influence the construction of certain structure of sukuk? Journal of Applied Finance and Banking, 3(5), pp. 251-267.

S\&P Global Ratings. (2016). Islamic Finance Outlook, 2017 Edition [online]. Available at: spglobal.com/ratings [Accessed 15 March 2017].

Thomson Reuters. (2016). Sukuk Perceptions and Forecast Study 2017: Poised For Growth. Available at: https://www.slideshare.net/EzzedineGHLAMALLAH/thomson-reuters-sukuk-preceptions-andforecast-study-2017 [Accessed 19 March 2017].

United Kingdom Trade \& Investment. (2014). UK Excellence in Islamic Finance. London: United Kingdom Trade \& Investment, URN UKTI/14/1144. 